\title{
Pengembangan Media Laboratorium Virtual Berbasis Inkuiri Materi Larutan Elektrolit dan Non-Elektrolit
}

\author{
Tia Rachmatika Wahyuni ${ }^{1}$, Sri Atun ${ }^{1}$ \\ ${ }^{1}$ Pendidikan Kimia-Universitas Negeri Yogyakarta
}

\begin{tabular}{l}
\hline \hline INFO ARTIKEL \\
\hline Riwayat Artikel: \\
Diterima: 23-04-2019 \\
Disetujui: 29-05-2019 \\
\hline
\end{tabular}

\section{Kata kunci:}

media development;

virtual laboratory;

inquiry;

pengembangan media;

laboratorium virtual;

inkuiri

\begin{abstract}
ABSTRAK
Abstract: This research aims to reveal the characteristics and quality of virtual chemistry laboratory based inquiry on electrolyte and non-electrolyte solution materials. The development procedure adapted the Borg and Gall model. Development is done through seven stages of information collecting planning, develop preliminary form of product, preliminary field testing, main product revision, main field testing, and operational product revision. The results of the research media software can be operated in Windows devices with virtual practicum and media products are very good quality based on material expert validation, peer reviewers, chemistry educator, learners, and have Good quality based on the validation of media experts, so it deserves to be used as a learning medium.
\end{abstract}

\begin{abstract}
Abstrak: Penelitian ini bertujuan untuk mengungkap karakteristik dan kualitas media laboratorium virtual berbasis inkuiri materi larutan elektrolit dan non-elektrolit. Prosedur pengembangan mengadaptasi model pengembangan Borg and Gall. Pengembangan dilakukan melalui tujuh tahapan yaitu pengumpulan data, perencanaan, pengembangan draft produk, uji coba lapangan awal, penyempurnaan hasil uji coba, uji coba lapangan, dan penyempurnaan produk hasil uji coba. Hasil penelitian yaitu software media dapat dioperasikan dalam perangkat Windows dengan praktikum secara virtual dan media memiliki kualitas sangat baik berdasarkan validasi ahli materi, peer reviewers, pendidik kimia, peserta didik, serta memiliki kualitas baik berdasarkan validasi ahli media, sehingga layak untuk digunakan sebagai media pembelajaran.
\end{abstract}

\author{
Alamat Korespondensi: \\ Tia Rachmatika Wahyuni \\ Pendidikan Kimia \\ Universitas Negeri Yogyakarta \\ Jalan Colombo No.1, Karang Malang, Caturtunggal Daerah Istimewa Yogyakarta 55281 \\ E-mail: rachmatikat@gmail.com
}

Perkembangan dunia abad 21 ditandai dengan pemanfaatan teknologi informasi dan komunikasi dalam segala segi kehidupan, termasuk dalam proses pembelajaran (Falode \& Gambari, 2017); (Jack \& Higgins, 2019); (Daryanto \& Karim, 2017). Proses pembelajaran yang tercantum dalam Kurikulum 2013 dapat dilakukan untuk meningkatkan mutu pendidikan, baik itu berupa hasil belajar peserta didik maupun kemampuan pendidik dalam melaksanakan proses pembelajaran. Contoh pemanfaatan Teknologi Komunikasi (IT) dalam pembelajaran adalah terciptanya laboratorium virtual sebagai pengganti atau pendukung laboratorium nyata (Tatli \& Ayas, 2013); (Arista \& Kuswanto, 2018); (Sanjuan et al., 2017). Masalah terbesar peserta didik dalam pembelajaran adalah miskonsepsi yang muncul terutama dalam pembelajaran kimia. Kesalahpahaman ini disebabkan karena pendidik hanya mengajarkan materi yang bersifat abstrak melalui pembelajaran di kelas, tidak dilengkapi dengan praktikum di laboratorium (Swandi, Hidayah, Irsan, 2014). Hal ini sesuai dengan pernyataan bahwa pembelajaran sains seperti kimia, fisika, biologi, dan mata pelajaran lain yang menggunakan laboratorium atau kegiatan di luar kelas merupakan kegiatan yang sangat penting karena memiliki dampak positif dalam pengajaran dan pembelajaran (Jagodziński \& Wolski, 2015).

Pembelajaran dengan metode praktikum melibatkan pengalaman peserta didik secara langsung dalam pembelajaran. Pengalaman langsung ini didapatkan dari interaksi peserta didik dengan media, sarana dan prasarana, serta komponen pembelajaran. Faktanya, masih banyak sekolah yang belum memiliki fasilitas laboratorium maupun kelengkapan-kelengkapan laboratorium. Data Kemendikbud menyatakan bahwa sebanyak 14 Sekolah Menengah Atas di Kabupaten Kebumen masih membutuhkan sarana dan prasarana khususnya laboratorium. Kekurangan sarana laboratorium di tingkat SMA dapat diminimalisir dengan adanya media pembelajaran berbasis praktikum yaitu media laboratorium virtual.

Keuntungan dari penggunaan laboratorium virtual yaitu dapat mengatasi masalah-masalah yang tidak dapat dipecahkan melalui praktikum biasa seperti miskonsepsi materi dan hubungannya dengan partikel-partikel makroskopis maupun mikroskopis (Hawkins \& Phelps, 2013); (Ambusaidi, Al-Mushawi, Al-Balushi, \& Al-Balushi, 2018). Kekurangan laboratorium nyata yang dapat diminimalisir dengan penggunaan laboratorium virtual yaitu keamanan penggunaan alat dan bahan laboratorium, kepercayaan diri peserta didik, dan dibutuhkannya waktu lebih untuk melakukan praktikum dengan hasil yang akurat (Tatli \& 
Ayas, 2013); (Falode \& Gambari, 2017). Animasi yang terdapat dalam pembelajaran yang menggunakan komputer dapat meningkatkan pemahaman konsep peserta didik dalam mempelajari materi sains. Kolaborasi antara media pembelajaran laboratorium virtual berbasis model pembelajaran inkuiri sangat beralasan karena media pembelajaran dapat membantu memvisualisasikan materi yang abstrak (Hawkins \& Phelps, 2013). Jika peserta didik telah menguasai seluruh aspek materi maka akan berdampak pada hasil belajarnya khususnya pada ranah kognitif. Model pembelajaran inkuiri dapat membantu peserta didik menemukan sendiri konsep materi pembelajarannya (Jagodziński \& Wolski, 2015).

Model pembelajaran inkuiri adalah model pembelajaran berbasis konstruktivis yaitu siswa belajar dari pengalaman (Koksal \& Berberoglu, 2014); (Mataka \& Kowalske, 2015). Tahap pembelajaran inkuiri dibagi menjadi lima langkah (1) peserta didik terlibat dalam pertanyaan inkuiri; (2) peserta didik mengeksplorasi jawaban atas pertanyaan dengan perencanaan, perancangan, hasil dari percobaan, dan rekaman hasil percobaan; (3) peserta didik membuat penjelasan dari data percobaan ke dalam jawaban pertanyaan; (4) peserta didik menguraikan, memperpanjang, atau menerapkan temuan mereka dalam konteks yang baru; (5) peserta didik mengevaluasi proses percobaan dan menghasilkan berbagai cara (Supasorn, 2015). National Research Council of the United States of America in the Inquiry and the National Science Education Standards menyatakan bahwa inkuiri adalah proses yang kompleks dengan tahap-tahapnya yaitu (1) merencanakan penyelidikan, menggunakan alat, menganalisis, dan menginterpretasikan data; (2) mengajukan pertanyaan; (3) mengumpulkan informasi yang terkait dengan masalah; (4) mengusulkan jawaban; (5) mengomunikasikan hasil (Szalay \& Tóth, 2016). Model pembelajaran inkuiri sangat cocok diterapkan dalam pembelajaran berbasis praktikum.

\section{METODE}

Media pembelajaran laboratorium virtual pada penelitian ini dikembangkan dengan mengacu pada model pengembangan (Borg \& Gall, 1989). Produk yang dihasilkan dalam penelitian ini adalah media pembelajaran laboratorium virtual berbasis inkuiri materi larutan elektrolit dan non-elektrolit. Prosedur pengembangan media laboratorium virtual berbasis inkuiri pada penelitian ini mengacu pada modifikasi dari model pengembangan Borg \& Gall. Model pengembangan Borg \& Gall terdiri atas tujuh tahapan.

Pertama, penelitian dan pengumpulan data. Tahap ini merupakan tahapan untuk mengumpulkan informasi mengenai latar belakang pengembangan media laboratorium virtual berbasis inkuiri. Lagkah-langkah pada tahap ini, meliputi mengumpulkan informasi mengenai permasalahan pembelajaran, mengumpulkan referensi mengenai materi larutan elektrolit dan non-elektrolit, dan mengumpulkan informasi mengenai pengembangan media laboratorium virtual. Kedua, perencanaan. Tahap ini merupakan tahap pembuatan desain media laboratorium virtual berbasis inkuiri materi larutan elektrolit dan non-elektrolit. Ketiga, pengembangan draft produk. Tahap ini merupakan lanjutan dari tahap dua, yaitu pengumpulan bahan dan referensi serta penyusunan media pembelajaran.

Keempat, uji coba lapangan awal. Tahap ini merupakan tahap penilaian produk kepada satu ahli media, satu ahli materi, tujuh peer reviewwer, dan pendidik kimia. Ahli media dan ahli materi adalah dosen yang berpengalaman di bidang pengembangan media dan dosen ahli materi kimia. Peer reviewer merupakan teman yang memahami standar kualitas media pembelajaran dengan baik. Kelima, penyempurnaan hasil uji coba. Pembetulan hasil uji coba lapangan awal berdasarkan masukan dan saran dari ahli media, ahli materi, peer reviewer, dan pendidik kimia. Keenam, uji coba lapangan. Uji coba lapangan terdiri dari uji coba skala terbatas dan uji coba skala kecil. Uji skala terbatas dilakukan kepada 20 peserta didik, sedangkan uji coba skala kecil dilakukan kepada 42 peserta didik untuk mengetahui saran dan masukan terhadap media yang dikembangkan. Ketujuh, penyempurnaan produk hasil uji coba. Pembetulan hasil uji coba lapangan awal berdasarkan dari hasil uji coba. Desain penilaian produk media pembelajaran laboratorium virtual berbasis inkuiri selengkapnya dapat dilihat pada gambar 1 .

\section{Instrumen Pengumpulan Data}

Instrumen yang digunakan dalam penelitian ini adalah lembar penilaian dan validasi media laboratorium virtual berbasis inkuiri yang terdiri dari lembar validasi ahli media dan ahli materi, lembar penilaian peer reviewer dan pendidik kimia; lembar penilaian kualitas oleh peserta didik.

Lembar penilaian dan validasi ahli media. Lembar validasi dan penilaian kualitas media, meliputi aspek tampilan audio visual dan audio serta aspek rekayasa perangkat lunak. Penilaian ini dilakukan pada saat uji coba lapangan awal. Setiap butir pernyataan memiliki skor maksimal 5 dan skor minimal 1. Kisi-kisi lembar validasi untuk ahli media dapat dilihat pada tabel 1. Lembar penilaian dan validasi ahli materi. Lembar validasi dan penilaian kualitas materi meliputi aspek materi dan aspek pembelajaran. Penilaian ini dilakukan pada saat uji coba lapangan awal. Setiap butir pernyataan memiliki skor maksimal 5 dan skor minimal 1. Kisi-kisi lembar validasi untuk ahli materi dapat dilihat pada tabel 2. 


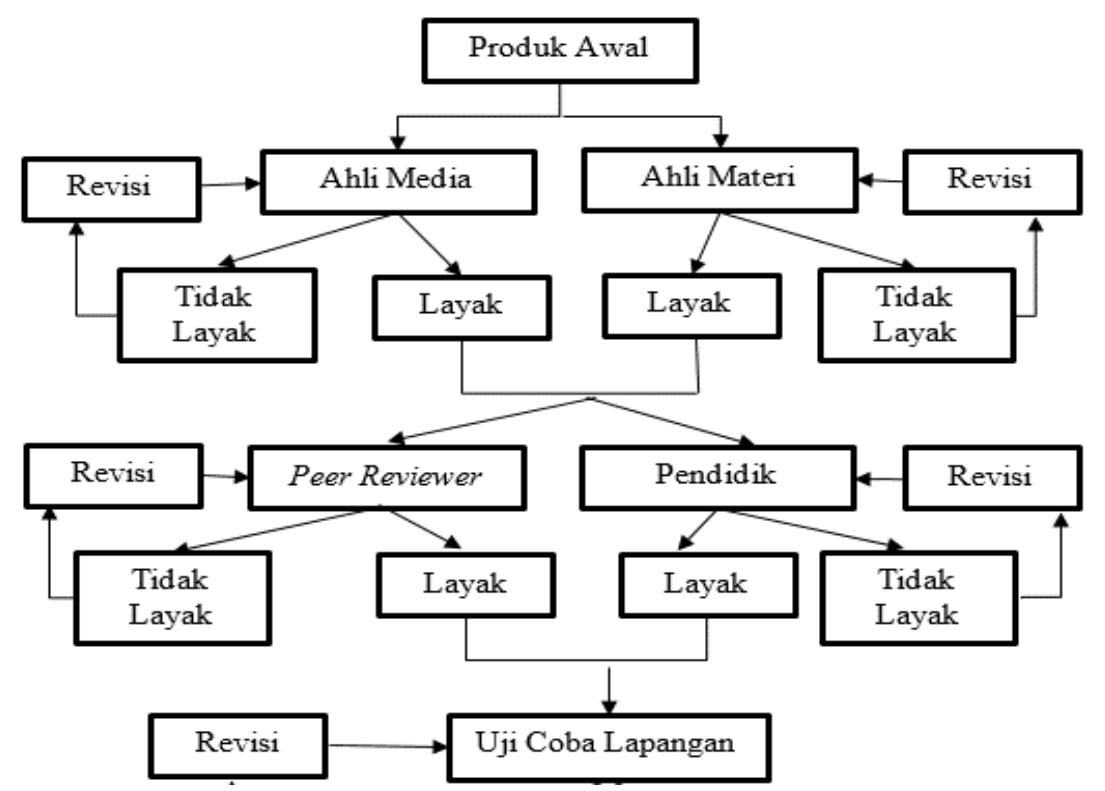

Gambar 1. Desain Penilaian Produk

Tabel 1. Kisi-kisi Lembar Validasi untuk Ahli Media

\begin{tabular}{ll}
\hline \multicolumn{1}{c}{ Aspek } & \multicolumn{1}{c}{ Butir Pernyataan } \\
\hline A. Visual dan Audio & 1.Penggunaan layout proporsional \\
& 2.Pemilihan warna \\
& 3.Pemilihan background sesuai konsep \\
& 4.Kejelasan teks \\
& 5.Posisi tombol navigasi konsisten \\
& 6.Pergerakan animasi menarik dan lancar \\
7.Kesesuaian animasi dengan konsep media & 8.Kesesuaian gambar pendukung dengan konsep media \\
& 9.Kesesuaian musik pengiring \\
\hline 10.Kemudahan pengoperasian media \\
11.Kejelasan petunjuk penggunaan media \\
12.Kreativitas dan inovasi dalam media pembelajaran \\
13.Kompatibilitas sistem operasi dengan program \\
14.Kesesuaian media untuk menunjukkan tingkat kemandirian belajar \\
15.Peluang pengembangan media terhadap IPTEK
\end{tabular}

Tabel 2. Kisi-kisi Lembar Validasi untuk Ahli Materi

\begin{tabular}{ll}
\hline \multicolumn{1}{c}{ Aspek } & \multicolumn{1}{c}{ Butir Pernyataan } \\
\hline A. Pembelajaran & 1.Kesesuaian indikator dengan kompetensi dasar (KD) \\
& 2.Kesesuaian materi larutan elektrolit dan non-elektrolit dengan indikator pembelajaran \\
& 3. Materi yang disajikan jelas \\
& 4.Kesesuaian kegiatan praktikum dengan indikator pembelajaran \\
& 5.Pemberian latihan soal pada media sesuai dengan materi \\
& 6. Kunci jawaban latihan soal sesuai dengan tes \\
& 7. Pilihan jawaban setara \\
& 8. Fasilitas media untuk melakukan praktikum virtual \\
\hline B. Materi / konten & 9.Materi dalam media menarik dan menumbuhkan kepercayaan diri \\
& 10. Kesesuaian bahasa dengan EYD \\
& 11. Kalimat yang digunakan baku \\
& 12.Kalimat yang digunakan tidak menimbulkan penafsiran ganda \\
13.Keruntutan lembar kerja praktikum
\end{tabular}


Lembar penilaian peer reviewer dan pendidik kimia. Penilaian produk media pembelajaran meliputi aspek visual dan audio, aspek rekayasa perangkat lunak, aspek pembelajaran, dan aspek materi/konten. Penilaian ini dilakukan pada saat uji coba lapangan awal. Setiap butir pernyataan memiliki skor maksimal 5 dan skor minimal 1. Kisi-kisi lembar penilaian peer reviewer dan pendidik kimia dapat dilihat pada tabel 3 .

Lembar penilaian peserta didik. Lembar penilaian kualitas produk media laboratorium virtual berbasis inkuiri, meliputi aspek materi, aspek pembelajaran, aspek tampilan, dan operasi media. Penilaian ini dilakukan pada saat uji coba lapangan. Setiap butir pernyataan memiliki skor maksimal 5 dan skor minimal 1. Kisi-kisi lembar penilaian peserta didik dapat dilihat pada tabel 4.

Tabel 3. Kisi-kisi Lembar Penilaian Peer Reviewer dan Pendidik Kimia

\begin{tabular}{|c|c|}
\hline Aspek & Butir Pernyataan \\
\hline \multirow[t]{9}{*}{ A. Visual dan Audio } & 1. Penggunaan layout proporsional \\
\hline & 2. Pemilihan warna \\
\hline & 3. Pemilihan background sesuai konsep \\
\hline & 4. Kejelasan teks \\
\hline & 5. Posisi tombol navigasi konsisten \\
\hline & 6. Pergerakan animasi menarik dan lancar \\
\hline & 7. Kesesuaian animasi dengan konsep media \\
\hline & 8. Kesesuaian gambar pendukung dengan konsep media \\
\hline & 9. Kesesuaian musik pengiring \\
\hline \multirow[t]{6}{*}{ B. Rekayasa Perangkat Lunak } & 10. Kemudahan pengoperasian media \\
\hline & 11. Kejelasan petunjuk penggunaan media \\
\hline & 12. Kreativitas dan inovasi dalam media pembelajaran \\
\hline & 13. Kompatibilitas sistem operasi dengan program \\
\hline & 14. Kesesuaian media untuk menunjukkan tingkat kemandirian belajar \\
\hline & 15. Peluang pengembangan media terhadap IPTEK \\
\hline \multirow[t]{7}{*}{ C. Pembelajaran } & 16. Kesesuaian materi larutan elektrolit dan non-elektrolit dengan tujuan pembelajaran \\
\hline & 17. Materi yang disajikan jelas \\
\hline & 18. Kesesuaian kegiatan praktikum dengan tujuan pembelajaran \\
\hline & 19. Pemberian latihan soal pada media sesuai dengan materi \\
\hline & 20. Kunci jawaban latihan soal sesuai dengan tes \\
\hline & 21. Pilihan jawaban setara \\
\hline & 22. Fasilitas media untuk melakukan praktikum virtual \\
\hline \multirow[t]{4}{*}{ D. Materi / konten } & 23. Materi dalam media menarik dan menumbuhkan kepercayaan diri \\
\hline & 24. Kesesuaian bahasa dengan EYD \\
\hline & 25. Kalimat yang digunakan baku \\
\hline & $\begin{array}{l}\text { 26. Kalimat yang digunakan tidak menimbulkan penafsiran ganda } \\
\text { 27. Keruntutan lembar kerja praktikum }\end{array}$ \\
\hline
\end{tabular}

Tabel 4. Kisi-kisi Lembar Penilaian Peserta Didik

\begin{tabular}{ll}
\hline \multicolumn{1}{c}{ Aspek } & \multicolumn{1}{c}{ Butir Pernyataan } \\
\hline A. Pembelajaran/ Materi & 1. Materi yang disajikan jelas \\
& 2. Penggunaan bahasa jelas \\
& 3. Media mudah diakses dalam pembelajaran \\
\hline B. Tampilan/ Operasional Media & 4. Pemilihan background, warna, animasi dan gambar sesuai \\
& 5. Ukuran huruf, gambar dan tombol sesuai \\
& 6. Animasi teks dan gambar menarik \\
7. Penempatan tombol sesuai & 8. Penggunaan musik pengiring sesuai \\
9. Media pembelajaran dapat berjalan dengan baik & 10. Media dapat dioperasikan dengan mudah \\
11. Petunjuk penggunaan jelas \\
\hline
\end{tabular}

\section{Metode Analisis Data}

Penilaian kelayakan media yang dikembangkan didasarkan pada hasil penilaian instrumen kelayakan materi dan media dari penilaian beberapa ahli, peer reviewer, dan pendidik kimia. Penilaian kualitas media yang diperoleh oleh ahli media, ahli materi, peer reviewer, pendidik kimia, dan peserta didik masih dalam bentuk data kualitatif. Selanjutnya, data tersebut diubah menjadi data kuantitatif dengan ketentuan sebagai berikut pada tabel 5. 
Pengubahan skor rata-rata menjadi nilai kualitatif untuk mengetahui kualitas media laboratorium virtual berbasis inkuiri sesuai dengan kriteria penilaian ideal (Widyoko, 2011), yang dijabarkan pada tabel 6.

\section{Tabel 5. Kriteria Kategori Skor}

\begin{tabular}{ccc}
\hline No & Kategori & Skor \\
\hline 1 & SB ( Sangat Baik) & 5 \\
\hline 2 & B (Baik) & 4 \\
\hline 3 & C (Cukup) & 3 \\
\hline 4 & K (Kurang) & 2 \\
\hline 5 & SK (Sangat Kurang) & 1 \\
\hline
\end{tabular}

Tabel 6. Kriteria Kualitas Media

\begin{tabular}{cc}
\hline Skor & Kriteria \\
\hline $\bar{X}>\bar{X}_{i}+1,8 \mathrm{SB}_{\mathrm{i}}$ & Sangat Baik \\
\hline $\bar{X}_{i}+0,6 \mathrm{SB}_{\mathrm{i}}<\bar{X}<\bar{X}_{i}+1,8 \mathrm{SB}_{\mathrm{i}}$ & Baik \\
\hline $\bar{X}_{i}-0,6 \mathrm{SB}_{\mathrm{i}}<\bar{X}<\bar{X}_{i}+0,6 \mathrm{SB}_{\mathrm{i}}$ & Cukup \\
\hline $\bar{X}_{i}-1,8 \mathrm{SB}_{\mathrm{i}}<\bar{X}<\bar{X}_{i}-0,6 \mathrm{SB}_{\mathrm{i}}$ & Kurang \\
\hline $\bar{X} \leq \bar{X}_{i}-1,8 \mathrm{SB}_{\mathrm{i}}$ & Sangat Kurang \\
\hline
\end{tabular}

$\mathrm{X}_{-}^{-} \mathrm{i}$ merupakan rata-rata ideal; $\mathrm{X}_{-}^{-} \mathrm{i}=1 / 2$ (skor tertinggi ideal + skor terendah ideal); SBi = simpangan baku ideal; SBi $=1 / 2 \times 1 / 3$ (skor tertinggi ideal - skor terendah ideal). Skor tertinggi ideal $=$ jumlah butir kriteria $\mathrm{x}$ skor tertinggi. Skor terendah ideal $=$ jumlah butir kriteria $\mathrm{x}$ skor terendah. Penilaian setiap aspek pada produk pengembangan media pembelajaran pada penelitian ini menggunakan skala likert dan dikatakan layak sebagai media pembelajaran, apabila total skor responden minimal mendapat kriteria baik.

\section{HASIL}

Prosedur penelitian dan pengembangan media laboratorium virtual berbasis inkuiri ini dilakukan dengan mengadaptasi model pengembangan Borg \& Gall (1983). Ketujuh tahap tersebut, meliputi penelitian dan pengumpulan data, perencanaan, dan pengembangan draft produk.

\section{Penelitian dan Pengumpulan Data}

Hasil observasi dan wawancara kepada pendidik mata pelajaran kimia kelas X dan beberapa peserta didik kelas X SMA Negeri 1 Gombong, ditemukan bahwa laboratorium kimia jarang digunakan untuk praktikum terutama ketika materi pelajaran kelas X. Hal ini dikarenakan terbatasnya alat dan bahan yang dimiliki laboratorium. Drs. Agus Purwanto selaku pendidik kelas X SMA Negeri 1 Gombong menyatakan bahwa alat praktikum untuk uji coba larutan elektrolit dan non-elektrolit masih sangat kekurangan. Kendala lain dalam mengajarkan materi ini adalah sulitnya peserta didik dalam memvisualisasikan ion-ion yang terdapat pada larutan elektrolit.

Media pembelajaran yang menguntungkan yaitu media yang menggunakan teknologi dalam mengakses informasi yang diperlukan peserta didik baik dari pendidik, teman sebaya dan aplikasi perangkat (Sugiana, Harjono, Sahidu, \& Gunawan, 2017). Memahami kimia mencakup kemampuan untuk berpikir pada tiga tingkatan: tingkat makroskopik, tingkat simbolik, dan tingkat partikel sub-mikroskopis (Herga \& Dinevski, 2016). Model pembelajaran inkuiri melatih peserta didik untuk menemukan sendiri konsep pembelajarannya (Jagodziński \& Wolski, 2015). Hal-hal yang perlu dijadikan sebagai pertimbangan yaitu perlu dikembangkan media laboratorium virtual yang dapat memvisualisasikan materi kimia yang bersifat abstrak dan penerapan model pembelajaran inkuiri dalam langkah pada menu praktikum karena model pembelajaran ini sangat cocok diterapkan pada pembelajaran berbasis praktikum.

\section{Perencanaan}

Tahap perencanaan adalah tahap penyusunan rancangan kasar desain media pembelajaran seperti materi dan bahasa penulisan media.

\section{Pengembangan Draft Produk}

Pengembangan produk merupakan tahapan merancang dan menyusun produk media laboratorium virtual berbasis inkuiri. Desain produk media laboratorium virtual berbasis inkuiri berupa flowchart dan storyboard, pengumpulan bahan dan referensi, dan penyusunan media pembelajaran. Pembuatan flowchart ini bertujuan untuk mempermudah menyusun produk dengan alur navigasi yang jelas sehingga mempermudah menyusun produk media. Pembuatan storyboard bertujuan untuk membuat beberapa frame dengan desain yang tepat, jelas dan menarik. Flowchart media ini dapat dilihat pada gambar 2 dan Storyboard dapat dilihat pada gambar 3 . 


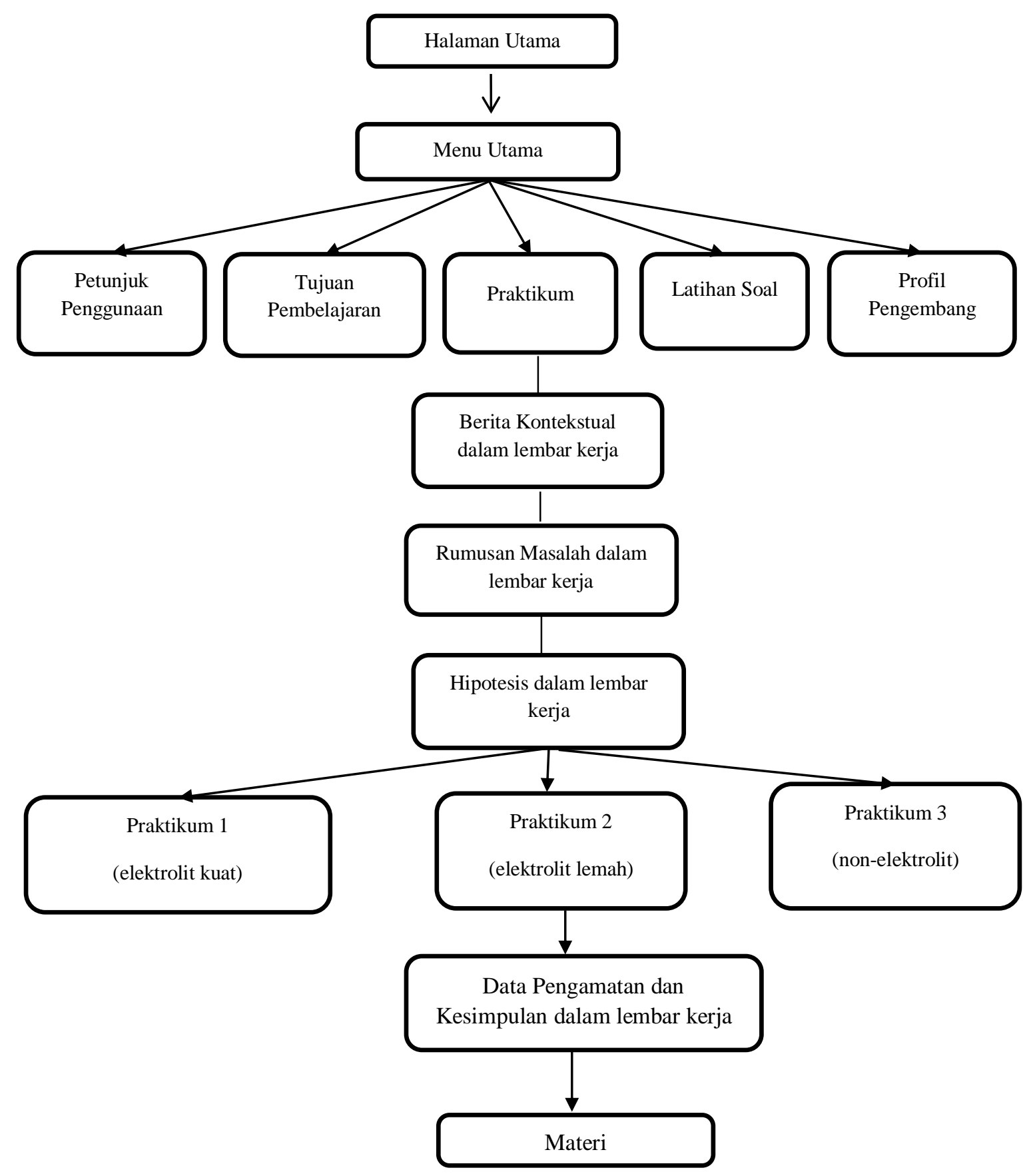

Gambar 2. Flowchart Media Laboratorium Virtual Berbasis Inkuiri 


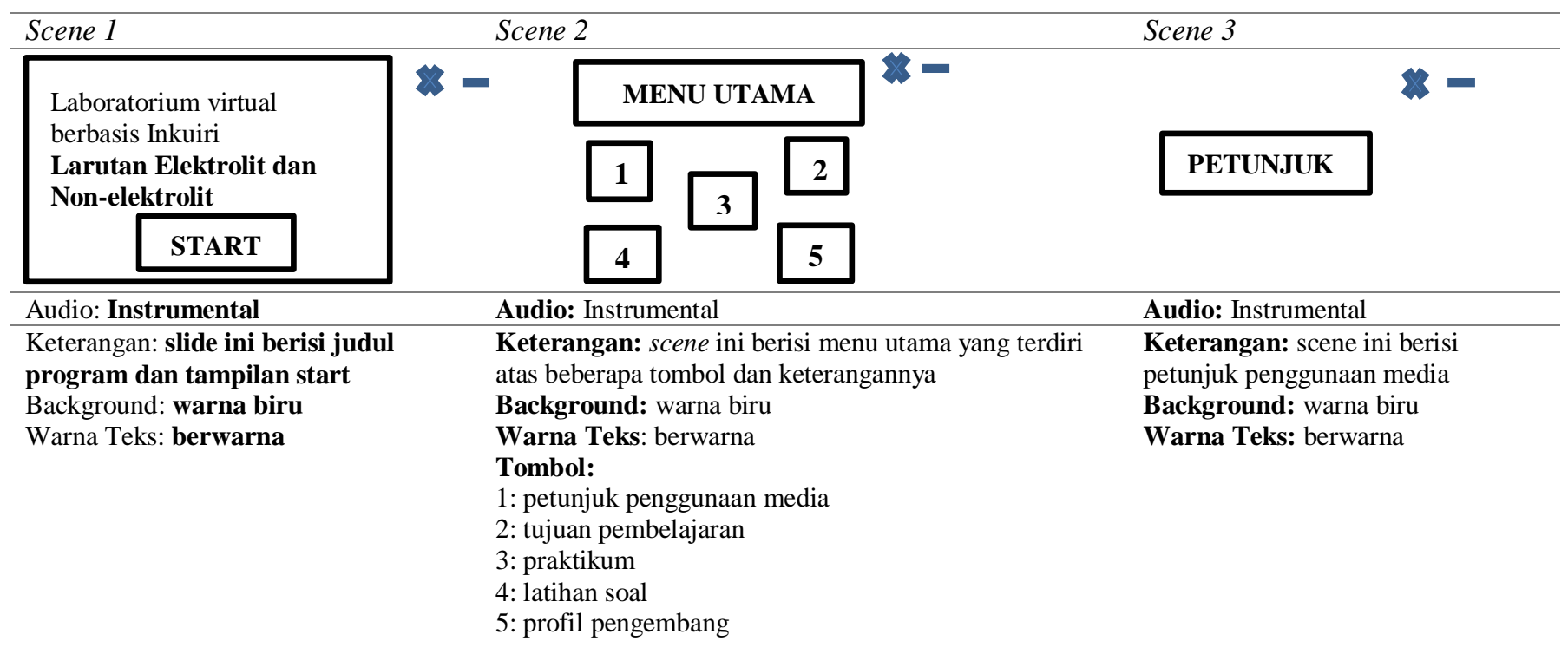

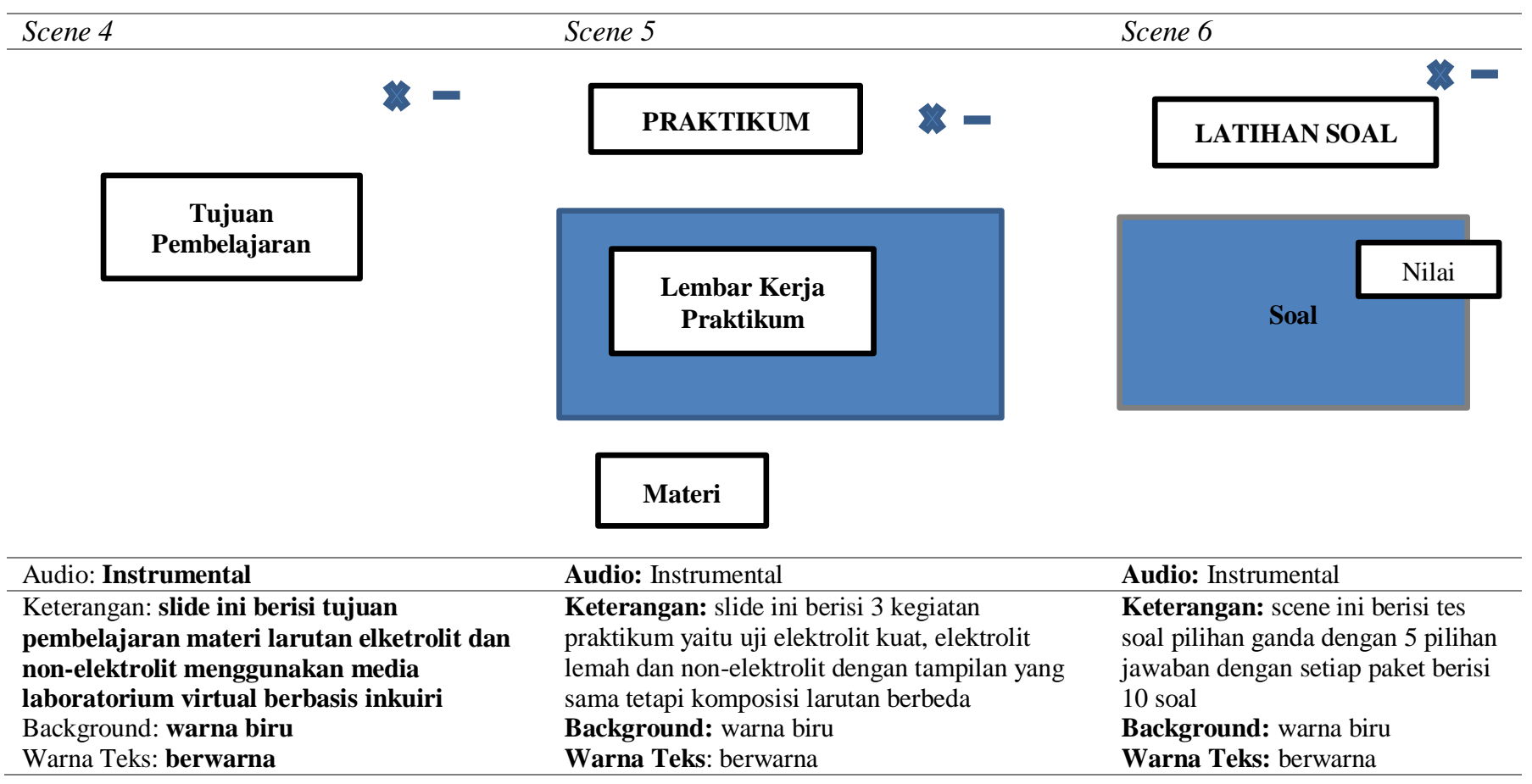

\section{Gambar 3. Storyboard Media Laboratorium Virtual Berbasis Inkuiri}

\section{Uji Coba Lapangan Awal}

Tahap validasi oleh ahli materi. Validasi yang dilakukan meliputi validasi konsep larutan elektrolit dan non-elektrolit dan soal-soal yang dikembangkan dalam media laboratorium virtual berbasis inkuiri. Hasil validasi oleh ahli materi didapatkan jumlah skor aspek pembelajaran sebesar 34 dari skor maksimal 40 sehingga termasuk kategori sangat baik. Aspek materi/konten didapatkan jumlah skor sebesar 20 dari skor maksimal 25 sehingga termasuk dalam kategori sangat baik. Total keseluruhan dari penilaian ahli materi adalah 54 dari skor maksimal 65, termasuk dalam rentang sangat baik (SB) sehingga aspek materi sudah layak untuk digunakan. Ahli materi juga memberikan saran untuk perbaikan produk awal media yang dikembangkan. Saran yang diberikan membenarkan dan menambahkan materi yang telah ditandai. 
Tahap validasi oleh ahli media. Validasi dilakukan oleh dosen yang berpengalaman dalam menggunakan berbagai software. Hasil validasi oleh ahli media didapatkan jumlah skor aspek visual dan audio sebesar 32 dari skor maksimal 45 sehingga termasuk dalam kategori baik. Aspek rekayasa perangkat lunak didapatkan jumlah skor sebesar 23 dari skor maksimal 30 sehingga termasuk dalam kategori baik. Hasil penilaian ahli media ini menunjukkan bahwa berdasarkan aspek visual dan audio serta aspek rekayasa perangkat lunak menunjukkan bahwa media laboratorium virtual berbasis inkuiri yang dikembangkan layak untuk digunakan dengan beberapa revisi.

Tahap penilaian oleh peer reviewer. Peer reviewer merupakan mahasiswa-mahasiswa yang melakukan penelitian di bidang pengembangan media yang keseluruhan adalah mahasiswa pascasarjana pendidikan kimia UNY. Hasil penilaian oleh peer reviewer didapatkan jumlah skor aspek visual dan audio sebesar 39 dari skor maksimal 45, aspek rekayasa perangkat lunak sebesar 27 dari skor maksimal 30, aspek pembelajaran sebesar 31,9 dari skor maksimal 35, aspek materi/konten sebesar 22,1 dari skor maksimal 25. Keempat aspek yang dinilai termasuk dalam kategori sangat baik. Hasil tersebut menyatakan bahwa keempat aspek penilaian dari peer reviewer menyatakan bahwa media yang digunakan telah layak digunakan. Peer reviewer juga memberikan beberapa saran untuk perbaikan produk awal yaitu menambahkan tombol mute untuk mematikan musik latar media.

Tahap penilaian oleh pendidik kimia. Pendidik kimia yang melakukan penilaian terhadap media laboratorium virtual berbasis inkuiri berasal dari unit pendidikan yang berbeda, yaitu dari SMAN 1 Gombong dan SMAN Karangsambung. Hasil penilaian oleh pendidik kimia didapatkan jumlah skor aspek visual dan audio sebesar 41 dari skor maksimal 45, aspek rekayasa perangkat lunak sebesar 27,8 dari skor maksimal 30, aspek pembelajaran sebesar 32,4 dari skor maksimal 35, aspek materi/konten sebesar 23,6 dari skor maksimal 25. Keempat aspek yang dinilai termasuk dalam kategori sangat baik. Hasil tersebut menyatakan bahwa keempat aspek penilaian dari pendidik kimia menyatakan bahwa media yang digunakan telah layak digunakan. Pendidik kimia juga memberikan beberapa saran untuk menu petunjuk lebih diperjelas lagi pada bagian petunjuk praktikum.

\section{Penyempurnaan Hasil Uji Coba}

Saran dari ahli materi, yaitu memberikan beberapa revisi pada bagian konten materi, khususnya terkait derajat ionisasi elektrolit kuat. Ahli media memberikan masukan seperti tampilan background pada gambar 4 diubah agar terlihat lebih sesuai materi seperti pada gambar 5. Ahli media juga memberikan saran pada tampilan berita seperti gambar 6 untuk ditambahkan tombol kembali dan petunjuk untuk membuka lembar kerja seperti pada gambar 7.

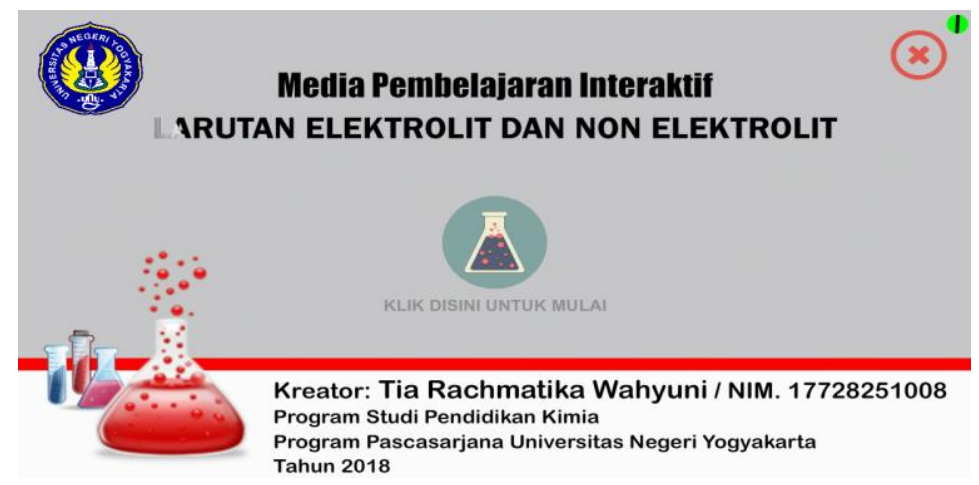

Gambar 4. Tampilan Background sebelum Revisi Ahli Media

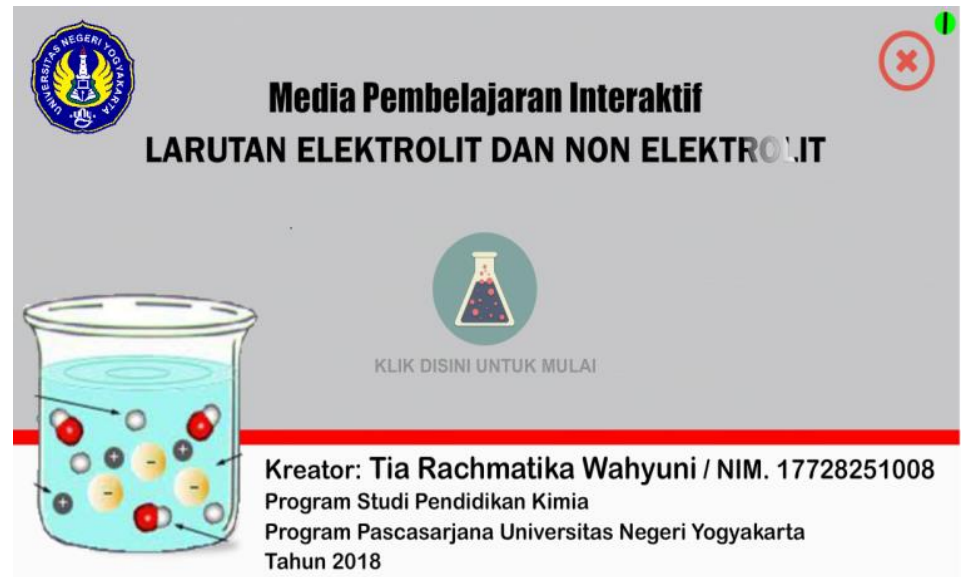

Gambar 5. Tampilan Background setelah Revisi Ahli Media 


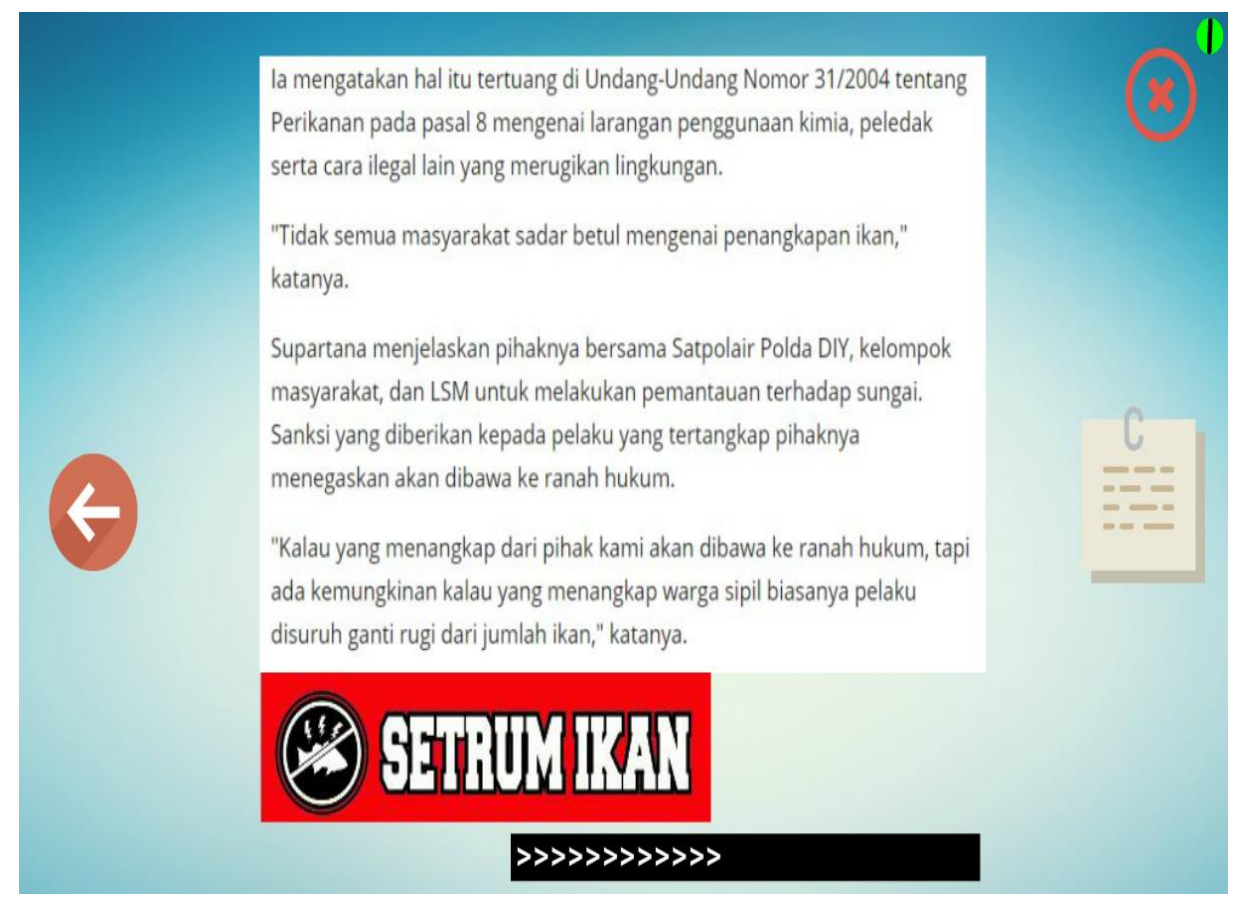

\section{Gambar 6. Tampilan Berita sebelum Revisi Ahli Media}

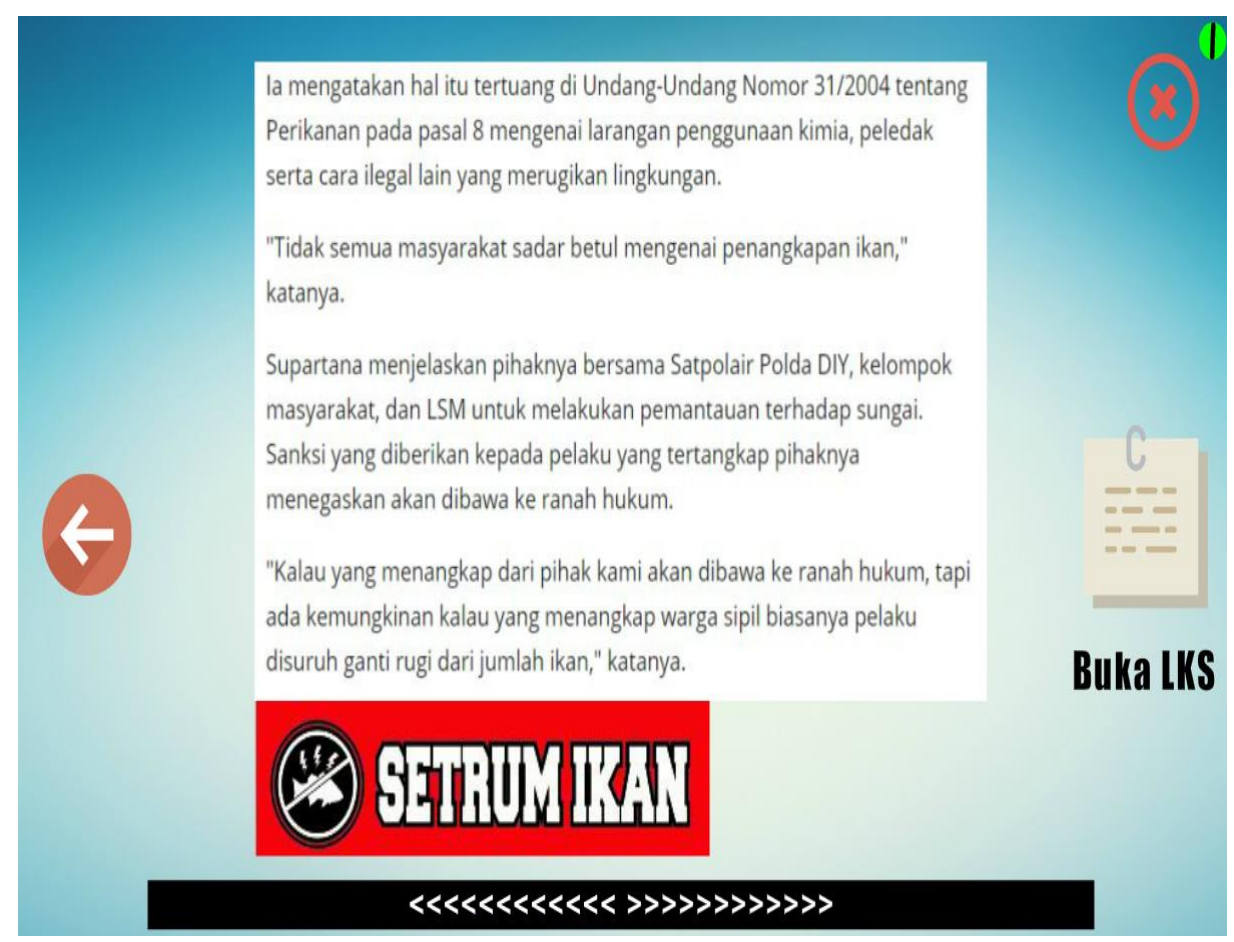

\section{Gambar 7. Tampilan Berita setelah Revisi Ahli Media}

Saran dari peer reviewer dan pendidik kimia. Penyerahan media untuk dinilai oleh peer reviewer dan pendidik kimia dilaksanakan setelah merevisi produk media berdasarkan saran dari ahli materi dan media. Peer reviewer dan pendidik kimia memberikan saran guna kesempurnaan produk yang dikembangkan. Saran yang diberikan yaitu pada gambar 8 ditambahkan tombol mute pada media seperti pada gambar 9. 


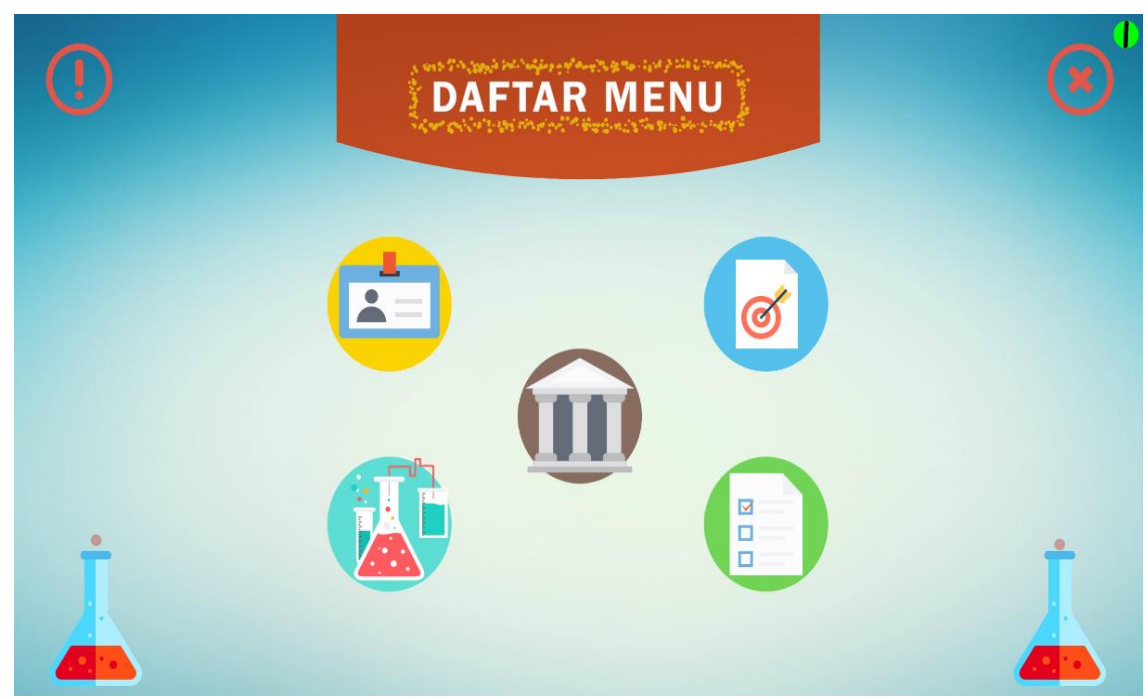

Gambar 8. Musik Latar sebelum Revisi Peer Reviewer dan Pendidik Kimia

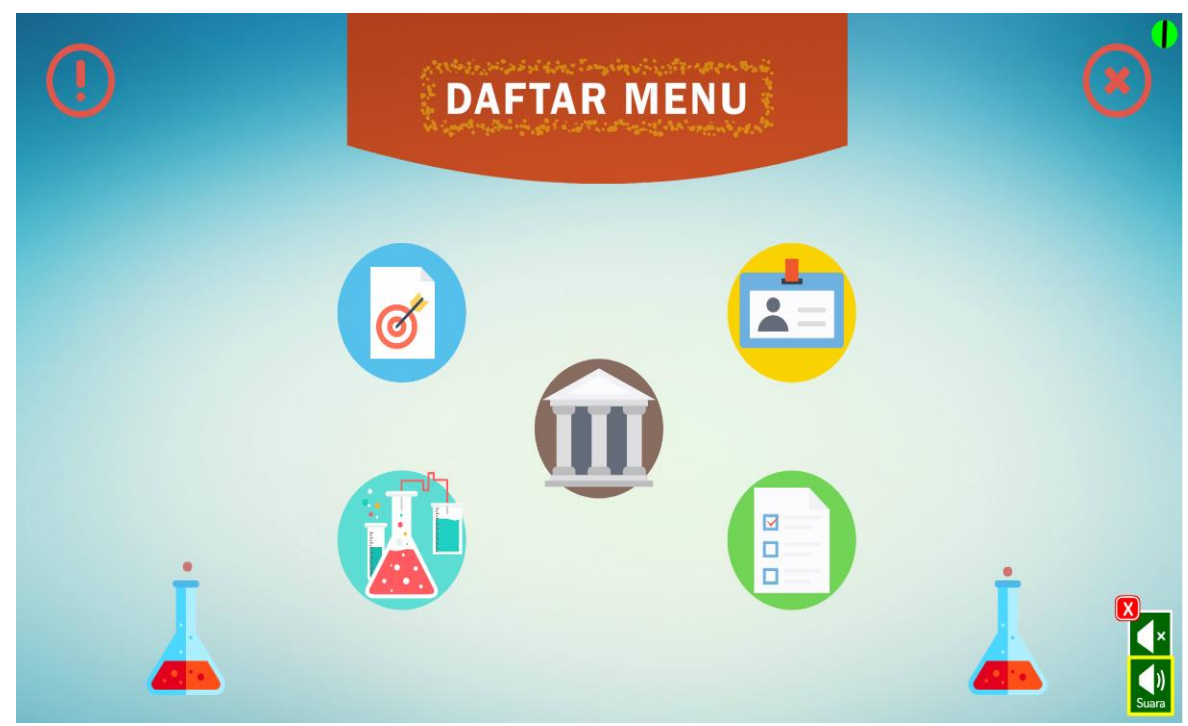

Gambar 9. Musik Latar setelah Revisi Peer Reviewer dan Pendidik Kimia

\section{Uji Coba Lapangan}

Uji coba terbatas. Hasil penilaian media dari uji coba terbatas menunjukkan bahwa aspek pembelajaran/materi pada media yang dihasilkan mempunyai kualitas sangat baik (SB) dengan rata-rata sebesar 13,1 dari skor maksimal 15. Aspek tampilan/operasional media juga memiliki kualitas sangat baik (SB) dengan rata-rata skor 36,6 dari skor maksimal 40. Saran dari peserta didik antara lain adalah menambahkan kata petunjuk dalam pengisian lembar kerja praktikum.

Uji coba skala kecil. Uji coba skala kecil dilakukan setelah merevisi produk media dari uji coba terbatas. Rata-rata skor hasil penilaian peserta didik pada aspek pembelajaran/materi pada media pengembangan adalah 13,2 dari skor maksimal 15 . Aspek tampilan/operasional media memperoleh rata-rata skor sebesar 35 dari skor maksimal 40. Kedua skor tersebut menunjukkan bahwa baik aspek pembelajaran/materi maupun tampilan/operasional media termasuk dalam kategori sangat baik (SB). Saran dari peserta didik yaitu setiap slide ditambahkan tombol home, seperti pada gambar 9 dan 10. 


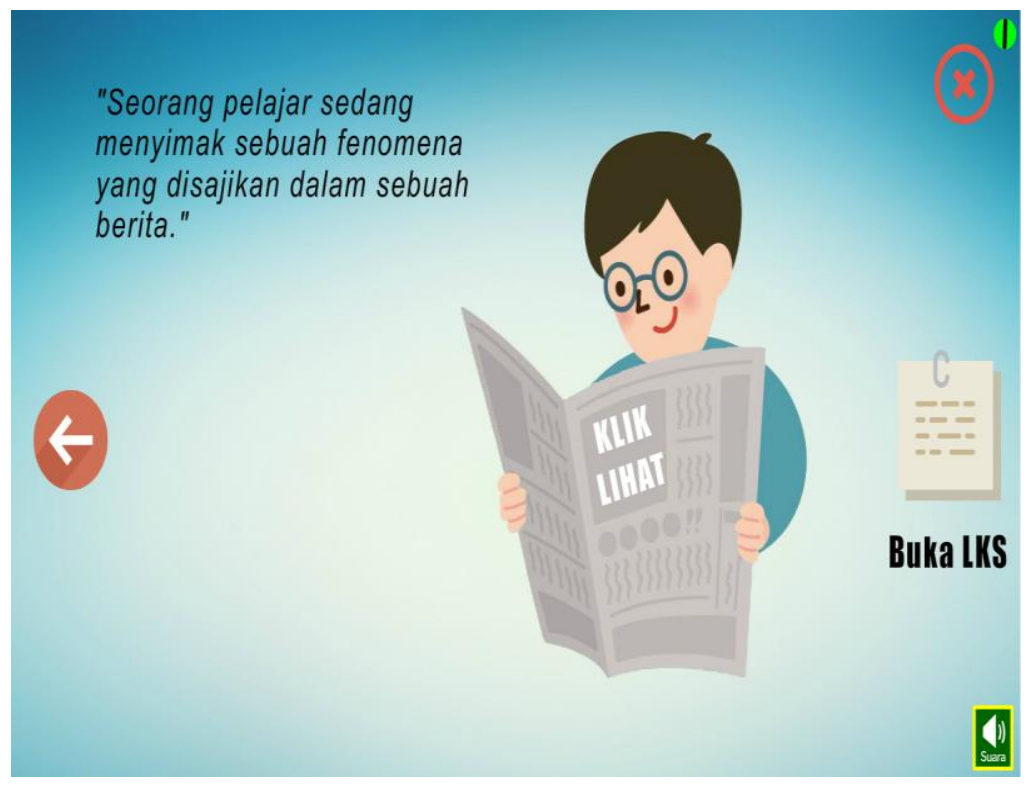

Gambar 9. Scene sebelum Uji Coba

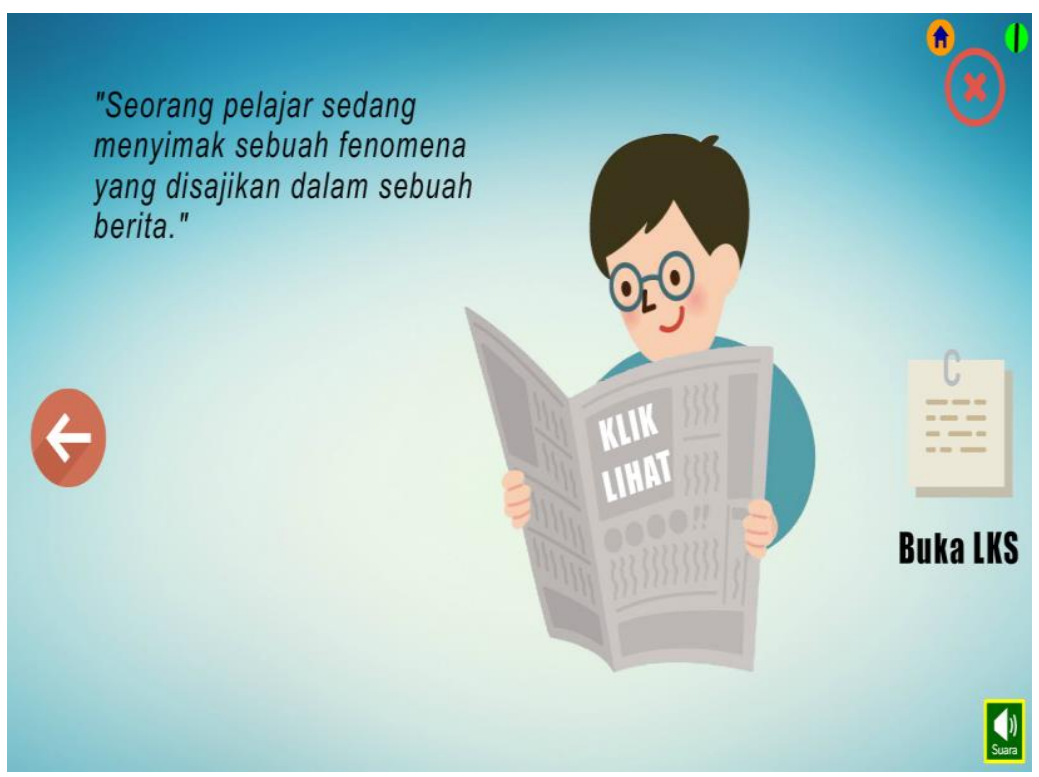

\section{Gambar 10. Scene setelah Uji Coba}

\section{PEMBAHASAN}

Pemanfaatan teknologi dalam pembelajaran sejalan dengan langkah pemerintah dalam penerapan kurikulum 2013 yaitu memperbaiki kualitas pembelajaran (Jack \& Higgins, 2019); (Kemendikbud, 2013). Materi larutan elektrolit dan non-elektrolit merupakan materi yang bersifat abstrak dengan tiga tingkat visualisasi yaitu tingkat makroskopik, mikroskopik, dan submikroskopik (Chang, 2010). Tingkat makroskopik membahas tentang jenis larutan, tingkat mikroskopik membahas tentang kemunculan gelembung dan tingkat sub-mikroskopik membahas tentang ion-ion dan elektron. Kesenjangan tingkat visualisasi ini hanya dapat dipahami peserta didik dengan bantuan teknologi. Selain itu, pembelajaran kimia merupakan pembelajaran yang berbasis praktikum sehingga banyak dari materi kimia dengan indikator pelaksanaan pembelajaran di laboratorium.

Media pembelajaran yang menguntungkan yaitu media yang menggunakan teknologi dalam mengakses informasi yang diperlukan peserta didik baik dari pendidik, teman sebaya dan aplikasi perangkat (Sugiana dkk., 2017). Pemanfaatan teknologi ini berupa software yang diterapkan dengan perangkat komputer yang diberi nama laboratorium virtual berbasis inkuiri. Media ini bermanfaat merangsang peserta didik untuk mengingat apa yang sudah dipelajari dan mengaktifkan peserta didik dalam memberikan tanggapan, umpan balik dan juga mendorong peserta didik untuk melakukan praktik-praktik dengan benar. 
Pemanfaatan laboratorium virtual ini dapat menjadi pendukung maupun pengganti laboratorium nyata (Hawkins \& Phelps, 2013); (Herga \& Dinevski, 2016); (Tatli \& Ayas, 2013); (Arista \& Kuswanto, 2018); (Sanjuan, Vilà, Piera, \& López, 2017). Inovasi yang diberikan dalam penelitian ini adalah perpaduan antara media dan model pembelajaran yaitu inkuiri. Model pembelajaran ini merangsang peserta didik secara aktif menemukan konsep-konsep pembelajaran (Jagodziński \& Wolski, 2015). Menu praktikum di dalam media ini juga berisi lembar kerja peserta didik berbasis inkuiri dalam bentuk Microsoft word.

Media laboratorium virtual berbasis inkuiri yang dikembangkan terdiri dari empat menu yaitu menu tujuan, praktikum, evaluasi, profil pengembang dan menu petunjuk. Langkah inkuiri yang digunakan pada menu praktikum mengacu kepada langkah inkuiri menurut (Supasorn, 2015) dan (Szalay \& Tóth, 2016) yang dimodifikasi sehingga langkah dalam media ini, meliputi (1) peserta didik merencanakan penyelidikan; (2) peserta didik terlibat dalam pertanyaan inkuiri; (3) peserta didik membuat hipotesis jawaban dari rumusan masalah; (4) peserta didik mengeksplorasi jawaban atas pertanyaan dengan perencanaan, perancangan, dan data hasil percobaan; (5) peserta didik menuliskan kesimpulan; (6) peserta didik diberikan materi sesuai dengan percobaan yang dilakukan.

Scene awal menu praktikum adalah bacaan berupa larangan menangkap ikan menggunakan alat setrum. Pemberian bacaan ini untuk memicu peserta didik menuliskan pertanyaan inkuiri pada lembar kerja yang disediakan. Selain menuliskan pertanyaan, peserta didik juga diminta untuk menuliskan hipotesis jawaban dari pertanyaan yang telah dibuat. Hal ini bertujuan untuk mengetahui kemampuan inkuiri awal peserta didik. Langkah selanjutnya adalah menuliskan perencanaan penyelidikan. Peserta didik diminta untuk memilih alat dan bahan yang akan digunakan untuk melakukan praktikum dan menggambarkan rangkaian alat uji elektrolit di lembar kerja. Susunan alat dan bahan praktikum yang telah dipilih selanjutnya digunakan untuk melakukan praktikum. Peserta didik diminta untuk menuliskan hasil percobaan uji elektrolit beberapa larutan dan menjawab pertanyaan-pertanyaan yang ada di lembar kerja. Materi di dalam media ini dapat dibuka oleh peserta didik setelah melaksanakan keseluruhan praktikum. Peletakan materi di akhir menu praktikum bertujuan untuk mencocokkan hasil praktikum dan jawaban pertanyaan peserta didik. Tahap terakhir adalah penulisan kesimpulan, pada tahap ini peserta didik menuliskan kesimpulan atas permasalahan, hasil praktikum, dan jawaban pertanyaan menjadi satu rangkaian cerita. Praktikum pada media ini terdiri dari tiga jenis yaitu praktikum elektrolit kuat, elektrolit lemah, dan non-elektrolit.

Praktikum elektrolit kuat di dalam media ini berisi larutan $\mathrm{H}_{2} \mathrm{SO}_{4}, \mathrm{CaCl}_{2}, \mathrm{HCl}, \mathrm{Ca}(\mathrm{OH})_{2}$, dan $\mathrm{NaCl}$ yang keseluruhan menghasilkan nyala lampu terang dan kemunculan gelembung di kedua elektrode setelah diuji menggunakan alat uji elektrolit. Praktikum elektrolit lemah terdiri dari larutan $\mathrm{CH}_{3} \mathrm{COOH}, \mathrm{HNO}_{2}$, yang menghasilkan nyala lampu redup dan sedikit gelembung dan $\mathrm{NH}_{3}$ yang hanya menghasilkan sedikit gelembung. Praktikum non-elektrolit terdiri dari larutan gula, alkohol, dan urea yang keseluruhan tidak menghasilkan nyala lampu dan tidak menghasilkan gelembung setelah diuji. Peserta didik dapat memperoleh pengetahuan mereka sendiri baik secara mandiri maupun kelompok menggunakan media laboratorium virtual berbasis inkuiri yang diberikan.

Penelitian ini mengadaptasi model penelitian dan pengembangan Borg \& Gall. Tahap awal adalah pengumpulan informasi berupa data-data dan teori yang diperlukan. Media dibuat berdasarkan flowchart dan storyboard untuk kemudian divalidasi oleh ahli materi dan ahli media. Ahli materi memvalidasi materi larutan elektrolit dan non-elektrolit yang disusun oleh peneliti. Hasil validasi ahli materi menunjukkan bahwa aspek pembelajaran dan materi/konten termasuk dalam kategori sangat baik. Ahli media memvalidasi aspek visual dan audio serta aspek rekayasa perangkat lunak, skor rata-rata kedua aspek tersebut termasuk ke dalam kategori baik. Hasil penilaian peer reviewer dan pendidik kimia terhadap media ini pada aspek visual dan audio, rekayasa perangkat lunak, pembelajaran, dan materi/konten seluruhnya memperoleh kategori sangat baik. Hasil uji coba skala terbatas dan skala kecil pada peserta didik diperoleh kategori sangat baik pada aspek pembelajaran/materi dan tampilan/operasional media. Keseluruhan hasil penilaian ini mengindikasikan bahwa media layak untuk dilakukan uji pelaksanaan lapangan. Penelitian ini terbatas pada pelaksanaan metode Borg \& Gall hanya sampai tahap ke tujuh yaitu revisi uji coba.

\section{SIMPULAN}

Media laboratorium virtual berbasis inkuiri yang telah dikembangkan memiliki karakteristik (1) media laboratorium virtual berbasis inkuiri berhasil dibuat dengan menggunakan program flash, (2) media dapat dioperasikan dalam perangkat berbasis windows, dan (3) media dapat dioperasikan kapanpun dan dimanapun dengan praktikum secara virtual.

Kualitas media laboratorium virtual berbasis inkuiri pada materi larutan elektrolit dan non-elektrolit yang telah dikembangkan termasuk dalam kategori sangat baik ditinjau dari penilaian aspek materi dan media yang dilakukan oleh ahli materi, pendidik kimia, peer reviewer, dan peserta didik serta termasuk dalam kategori baik ditinjau dari aspek penilaian ahli media. Perlu dikembangkan media serupa dengan materi yang lain untuk melengkapi media pembelajaran setiap materi baik pendukung ataupun pengganti praktikum nyata. Perlu dikembangkan dalam perangkat android agar lebih mudah dalam pengoperasiannya. 


\section{DAFTAR RUJUKAN}

Ambusaidi, A., Al Musawi, A., Al-Balushi, S., \& Al-Balushi, K. (2018) The Impact of Virtual Lab Learning Expriences on 9th Grade Student's Achievement and their Attitudes Towards Science and Learning by Virtual Lab. Journal of Turkish Science Education, 15(2), 13-29. doi: 10.12973/tused.10227a

Arista, F.S., \& Kuswanto, H. (2018). Virtual Physics Laboratory Application based on the Android Smartphone to Improve Learning Independence and Conceptual Understanding. International Journal of Instruction, 11, 1-16. https://doi.org/10.12973/iji.2018.1111a

Borg., \& Gall. (1989). Educational Research. An Introduction (5th ed.). New York: Addison Wesley Longman, Inc.

Daryanto, \& Karim, S. (2017). Pembelajaran Abad 21. Yogyakarta: Gava Media.

Sanjuan, A. F., Vila, R. P., Piera, F. F., \& Lopez, S. D. F. (2017). Laboratory 3.0: Manufacturing Technologies Laboratory Virtualization with a Student-Centred Methodology. Journal of Technology and Science Education, 7, 184-202. https://doi.org/10.3926/jotse.249

Herga, N. R., \& Dinevski, D. (2016). Virtual Laboratory in the Role of Dynamic Visualisation for Better Understanding of Chemistry in Primary. Eurasia Journal of Mathematics, Science \& Technology Education, 12(3), 593-608. doi: 10.12973/eurasia.2016.1224a

Fabregat-Sanjuan, A., Pàmies-Vilà, R., Ferrando Piera, F., \& De la Flor López, S. (2017). Laboratory 3.0: Manufacturing Technologies Laboratory Virtualization with a Student-Centred Methodology. Journal of Technology and Science Education, 7(2), 184. https://doi.org/10.3926/jotse.249

Falode, O. C., \& Gambari, A. I. (2017). Evaluation of Virtual Laboratory Package on Nigerian Secondary School Physics Concepts. Turkish Online Journal of Distance Education, 168-168. https://doi.org/10.17718/tojde.306567

Hawkins, I., \& Phelps, A. J. (2013). Virtual Laboratory vs. Traditional Laboratory: Which is More Effective for Teaching Electrochemistry? Chemistry Education Research Practice, 14(4), 516-523. https://doi.org/10.1039/C3RP00070B

Jack, C., \& Higgins, S. (2019). Embedding Educational Technologies in Early Years Education. Research in Learning Technology, 27(0). https://doi.org/10.25304/rlt.v27.2033

Jagodziński, P., \& Wolski, R. (2015). Assessment of Application Technology of Natural User Interfaces in the Creation of a Virtual Chemical Laboratory. Journal of Science Education and Technology, 24(1), 16-28. https://doi.org/10.1007/s10956-014-9517-5

Kemendikbud. (2013). Permendikbud Nomor 81 A Tahun 2013 tentang Implementasi Kurikulum. https://luk.staff.ugm.ac.id/atur/bsnp/Permendikbud81A-2013Implementasi K13 Lengkap.pdf

Koksal, E. A., \& Berberoglu, G. (2014). The Effect of Guided-Inquiry Instruction on 6th Grade Turkish Students' Achievement, Science Process Skills, and Attitudes Toward Science. International Journal of Science Education, 36(1), 66-78. https://doi.org/10.1080/09500693.2012.721942

Mataka, L. M., \& Kowalske, M. G. (2015). The Influence of PBL on Students' Self-Efficacy Beliefs in Chemistry. Chemistry Education Re https://doi.org/10.1039/C5RP00099H

Sugiana, I. N., Harjono, A., Sahidu, H., \& Gunawan, G. (2017). Pengaruh Model Pembelajaran Generatif Berbantuan Media Laboratorium Virtual terhadap Penguasaan Konsep Fisika Siswa pada Materi Momentum dan Impuls. Jurnal Pendidikan Fisika dan Teknologi, 2(2), 61. https://doi.org/10.29303/jpft.v2i2.290

Supasorn, S. (2015). Grade 12 Students' Conceptual Understanding and Mental Models of Galvanic Cells Before and After Learning by Using Small-Scale Experiments in Conjunction with a Model kit. Chemistry Education Research and Practice, 16(2), 393-407. https://doi.org/10.1039/C4RP00247D

Suwandi, A., Hidayah, S. N., \& Irsan, L. J. (2014). Pengembangan Media Pembelajaran Laboratorium Virtual untuk Mengatasi Miskonsepsi pada Materi Fisika Inti di SMAN 1 Binamu, Jeneponto. Jurnal Fisika Indonesia, 52, 20-24.

Szalay, L., \& Tóth, Z. (2016). An Inquiry-Based Approach of Traditional 'step-by-step' Experiments. Chemistry Education Research and Practice, 17(4), 923-961. https://doi.org/10.1039/C6RP00044D

Tatli, Z., \& Ayas, A. (2013). Effect of a Virtual Chemistry Laboratory on Students' Achievement. Educational Technology \& Society, 16(1), 159-170. https://www.j-ets.net/ets/journals/16_1/14.pdf 